https://nv.nltu.edu.ua

https://doi.org/10.36930/40290915

\title{
ФОТОСИНТЕТИЧНІ ІНДИКАТОРИ СТАНУ ЗАБРУДНЕННЯ АТМОСФЕРНОГО ПОВІТРЯ ПОКУТСЬКО-БУКОВИНСЬКИХ КАРПАТ
}

Досліджено взаємозв'язок стану атмосферного повітря та показників фотосинтетичного апарату представників дендрофлори Покутсько-Буковинських Карпат бука звичайного (Fagus silvatica L.) та тополі пірамідальної (Topulus pyramidalis Moenoh.), що вегетують в умовах різного антропогенного навантаження. Зразки листків відбирали із чотирьох екотопів, що відрізняються рівнем функціонального призначення та забруднення атмосферного повітря. Вивчено вміст хлорофілів та їх співвідношення, а також інтенсивність процесів світлової фази фотосинтезу. Встановлено, що зменшення відносного вмісту хлорофілу "b" в умовах забруднення атмосферного повітря тісно корелює із швидкістю переносу електронів по електронтранспортному ланцюгу (реакція Хілла). У порівняно чистих, за показниками атмосферного повітря, територіях (заповідній зоні та зоні стаціонарної рекреації національного природного парку) існує тісна позитивна кореляція між вмістом легких негативних аероіонів, нагромадженням зелених пігментів та активністю фотофізичних процесів. Побудовано кореляційну матрицю взаємозалежності показників активності фотосинтетичного апарату рослин та стану атмосферного повітря досліджених територій. Обгрунтовано доцільність використання фотосинтетичних показників дендрофлори заповідної зони об'єктів природоохоронних територій як індикаторів стану екологічної безпеки атмосферного повітря. Результати досліджень опрацьовано статистично.

Ключові слова: фотосинтетичні показники; якість атмосферного повітря; антропогенне навантаження; еталонні території; кореляційний аналіз.

Вступ. Оцінювання стану повітряного басейну територій є однією із важливих складових частин моніторингу довкілля. Існує низка підходів до вивчення якості та з'ясування рівня екологічної безпеки атмосферного повітря. Рослини є своєрідними посередниками між екотопом та біогенним середовищем, вони є першими в ланцюгу поглинання та колообігу енергії i, саме тому виступають надійним індикатором стану довкілля та атмосферного повітря зокрема. Порушення газового складу атмосфери, забруднення різного роду полютантами позначається на активності фотосинтетичних процесів, які виступають свого роду індикаторами стану повітряного середовища.

Об'єктом дослідження є вивчення взаємозв'язку стану атмосферного повітря та показників фотосинтетичного апарату представників дендрофлори Покутсько-Буковинських Карпат.

Предметом дослідження є показники стану фотосинтетичного апарату різних за природоохоронним статусом територій.

Мета дослідження - дослідити фотосинтетичні показники листяних лісоформівних порід Покутсько-Буковинських Карпат в екотопах, що відрізняються рівнем антропогенного навантаження та екологічної безпеки.

Завданнями дослідження є:
- вивчити вміст хлорофілів та їх співвідношення в листках бука звичайного (Fagus silvatica L.) та тополі пірамідальної (Topulus pyramidalis Moenoh.), що вегетують у заповідній зоні, зоні стаціонарної рекреації, господарській зоні національного природного парку "Вижницький" (надалі - НПП) та прилеглих територіях традиційного ведення господарства;

- дослідити інтенсивність процесів світлової фази фотосинтезу шляхом вивчення активності реакції Хілла в рослин зазначених вище територій різного природоохоронного статуcy;

- побудувати кореляційну матрицю взаємозалежності показників активності фотосинтетичного апарату рослин та стану атмосферного повітря досліджених територій;

- обгрунтувати доцільність використання фотосинтетичних показників дендрофлори заповідної зони об'єктів природоохоронних територій як індикаторів стану екологічної безпеки атмосферного повітря.

Аналіз літературних джерел. За умов техногенного забруднення атмосферного повітря, через функціональні особливості, рослини першими потрапляють у ситуацію екологічного стресу, реагують на ці впливи зміною форми, функцій та метаболізму (Lucyshyn et al., 2010; Odukalecz', 2011).

На думку багатьох авторів (Masikevych, 2010; Masikevych \& Masikevych, 2011), фотосинтез є одним із найчутливіших фізіологічних процесів до дії стресових екологічних факторів, і успішно може використовува-

\section{Інформація про автора:}

Масікевич Андрій Юрійович, канд. техн. наук, доцент, кафедра гігієни та екології. Email: masikevich_a@gmail.com; https://orcid.org/0000-0003-2862-9671

Цитування за ДСтУ: Масікевич А. Ю. Фотосинтетичні індикатори стану забруднення атмосферного повітря ПокутськоБуковинських Карпат. Науковий вісник НлтУ України. 2019, т. 29, № 9. С. 87-91.

Citation APA: Masikevich, A. Yu. (2019). Photosynthetic indicators of the atmospheric air pollution status of the Pokutsko-Bukovinian Carpathians. Scientific Bulletin of UNFU, 29(9), 87-91. https://doi.org/10.36930/40290915 
тися для індикації чистоти атмосферного повітря. Так, дослідженнями (Yusypiva \& Vegerych, 2014) показано вплив антропогенного навантаження на динаміку концентрації фотосинтезувальних пігментів у листках Betula pendula L., Robinia pseudoacacia L. та Salix alba L. в умовах степового Придніпров'я. Автори виявили, що під дією промислового забруднення вміст суми хлорофілів $(\mathrm{a}+\mathrm{b})$ нижчий у дослідних рослин порівняно з контрольними. Показано, що атмосферні забруднювачі зменшують концентрацію окремих форм зелених пігментів листка. Дослідженнями (Shupranova et al., 2017) встановлено, що за умов високого рівня забруднення атмосфери полютантами спостерігається тенденція до зниження вмісту хлорофілів "a" i "b" та їх суми. Автори показали, що найвищі показники нагромадження пігментів виявлено в умовах середнього, а найнижчі - високого рівня забруднення атмосфери викидами автотранспорту, при цьому вміст хлорофілу "а" знижується істотніше за хлорофіл "b". Відношення хлорофіл "a"/хлорофіл "b" у дерев дуба звичайного I і II класів життєвості змінюється незначно, що дає змогу рослинам підтримувати стабільність співвідношення між комплексами реакційних центрів фотосистем і світлозбирального комплексу ФС II. Вміст суми хлорофілів у листках дуба звичайного перебував у межах 4,006,06 мг/г сирої ваги.

Автори (Popek et al., 2018) вивчили нагромадження твердих частинок (ТЧ) на листках та вплив цих частинок на ефективність роботи фотосинтетичного апарату семи видів рослин, що вегетують у центрі Варшави та передмістях, які відрізняються рівнем забруднення повітря ТЧ. Показано, що значне нагромадження твердих частинок на листках рослин спричиняє зниження рівня інтенсивності фотосинтезу, що пояснюється блокуванням продихів ТЧ.

Дослідженнями ( $\mathrm{Lu}, 2019)$ вивчено реакцію-відповідь фотосинтетичних процесів ряду деревоподібних форм рослин в умовах забруднення атмосферного повітря частинками пилу різного розміру.

Дослідники (Shepelyuk et al., 2017) вивчили вплив різних за інтенсивністю несприятливих техногенних факторів на індукцію флуоресценції хлорофілу семи видів дерев урбанізованих територій. Встановлено високу пластичність структурної організації хлоропластів до умов вегетації, показано, що рослини паркової зони міста характеризуються кращими коефіцієнтами ефективності темнових фотохімічних реакцій.

Незважаючи на те, що заповідні території, по праву, виступають своєрідними еталонами природи (Mudrak et al., 2014) фотосинтетичні показники корінних листяних лісоформівних порід цих об'єктів вивчені недостатньо. Ще недостатньою мірою вивчено фотосинтетичні показники дендрофлори заповідних зон природоохоронних об'єктів як еталонів для з'ясування рівня забруднення атмосфери територій, що зазнають інтенсивного антропогенного навантаження.

Матеріал і методи дослідження. Для отримання усередненої проби рослинного матеріалу відбирали листки із чотирьох сторін нижнього ярусу крони п'яти приблизно одновікових рослин бука звичайного (Fagus silvatica L.) та тополі пірамідальної (Topulus pyramidalis Moenoh.), що вегетують у різних, за природоохоронним статусом, територіях Покутсько-Буковинських Карпат. Пункти відбору проб листків подано на рис. 1.

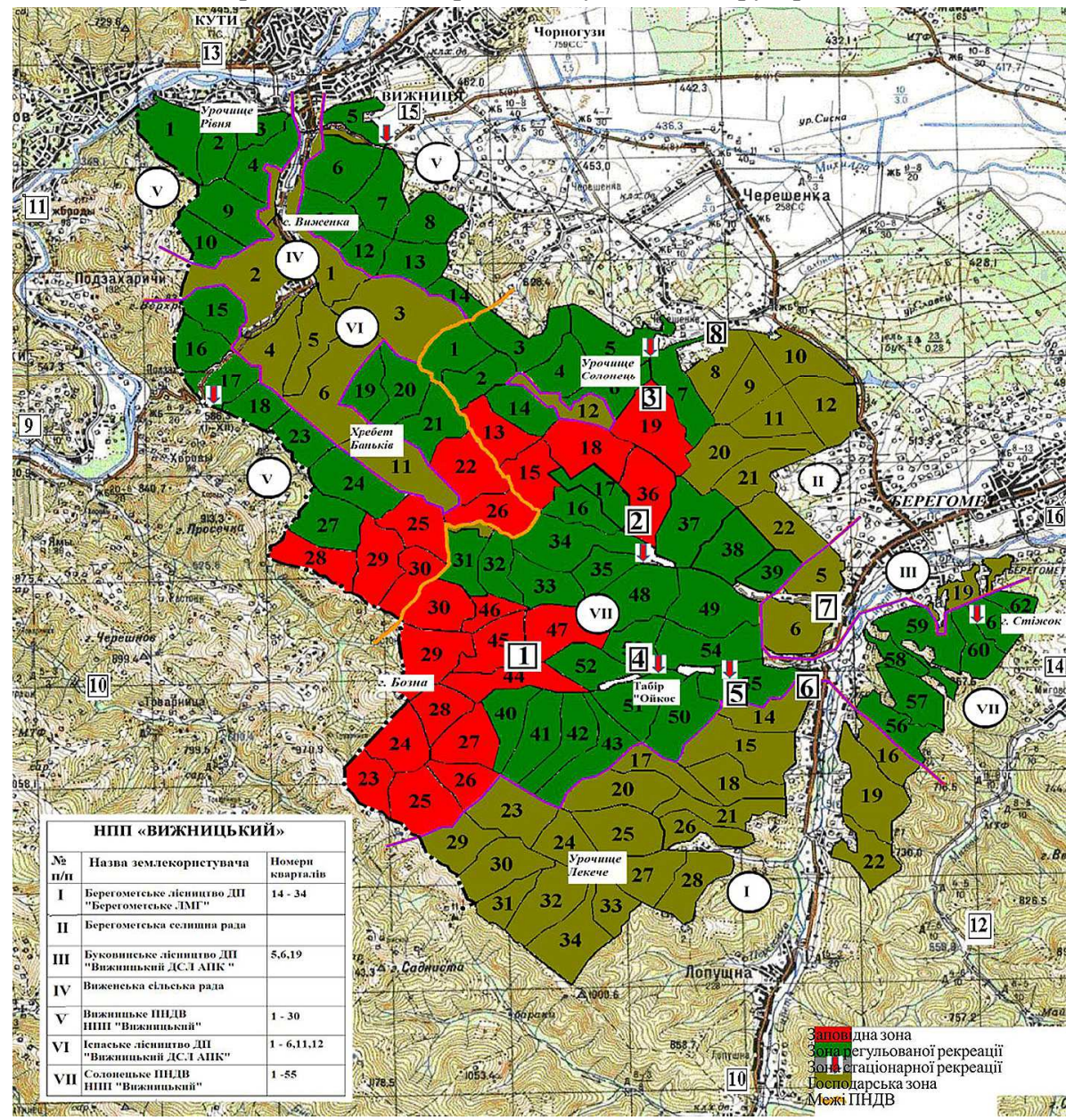

Рис. 1. Карта-схема функціонального зонування національного природного парку "Вижницький" та пунктів забору проб 
Зразки листків відбирали із чотирьох екотопів, що відрізняються рівнем антропогенного навантаження та функціонального призначення:

- заповідна зона НПП - чистий стан атмосферного повітря (позначена на картосхемі червоним кольором), пункти відбору проб № 1-3;

- зона регульованої рекреації із невеличкими вкрапленнями територій стаціонарної рекреації - відносно чистий стан атмосферного повітря (темно-зелений колір), пункти відбору проб № 4, 5;

- господарська зона (оливковий колір), пункти відбору проб № 6-8;

- зона ландшафтів традиційного господарювання (території, що прилягають до НПП в межах 10-кілометрової зони), пункти відбору проб № 9-15.

Концентрацію хлорофілу в суспензії та вимір швидкості реакції Хілла проводили спектрофотометрично за методом (Gavrylenko \& Khandobyna, 1975). Для визначення активності реакції Хілла готували реакційну суміш, що вміщувала: 4 мл суспензії хлоропластів, еквівалентне 50-100 мкг хлорофілу 1 мл водного розчину фериціаніду калію (акцептор електронів), який містив 2 мкM 0,4 M сахарози, 100 мМ NaCl, 2 мМ $\mathrm{MgCl}_{2}$. Визначення оптичної густини проводили при 420 нм на СФ-26 упродовж 4-5 хв через кожну хвилину освітлення проти стандартного розчину (4 мл суспензії хлоропластів +1 мл $\mathrm{H}_{2} \mathrm{O}$ ). Розраховували зміну оптичної густини під час експерименту для дослідної (світло) та контрольної проб.

Результати дослідів опрацьовані статистично, повторність дослідів чотирьохкратна, різниця достовірна при р < 0,05 (Demkiv et al., 2008).

Результати дослідження та їх обговорення. Отримані результати свідчать про те, що рослини бука звичайного (Fagus silvatica L.) заповідної зони НПП значно переважають за вмістом хлорофілів "a" i "b" представників цього виду, які вегетують у господарській зоні
НПП та на територіях прилеглих господарських ландшафтів (табл. 1). При цьому, при переході до територій із більш забрудненим атмосферним повітрям, існує тенденція до стрімкішого зменшення в листках хлорофілу "b", про що свідчить зростання співвідношення між зазначеними формами хлорофілів. Аналогічна тенденція характерна також для представника іншого виду місцевої флори - тополі пірамідальної. Проте для тополі пірамідальної - стійкого виду до забруднення повітряного середовища, характерним є незначне зменшення обох форм хлорофілів у межах 10-11\% (для хлорофілу "a") та 21-22\% (для хлорофілу "b") від контрольного показника, якщо порівняти з більш чутливим до забруднення атмосферного повітря бука звичайного, показник деградації пігментного апарату в якого сягає до $33 \%$.

Порівняльний аналіз проведених досліджень (див. табл. 1) свідчить про те, що нагромадження зелених пігментів перебуває у безпосередній залежності від віддаленості розміщення досліджених видів рослин від автомагістралей та інших стаціонарних джерел забруднення. Так, для рослини територій традиційного господарювання характерним є значне зменшенням вмісту обох форм хлорофілів, особливо хлорофілу "b".

3 наближенням до джерела забруднення спостерігається збільшення величини співвідношення хлорофілів "a"/"b" в 1,3-1,5 раза. Імовірно, токсиканти нагромаджуючись у хлоропластах, спричиняють деструкцію та розпад пігментів, особливо це стосується хлорофілу "b". Відомо, що зміна вмісту хлорофілу "b" в листках рослин призводить до зміни структури їх фотосинтетичного апарату рослин (Shupranova et al., 2017).

За результатами нашого дослідження встановлено, що зменшення відносного вмісту хлорофілу "b" в умовах забруднення атмосферного повітря тісно корелює із швидкістю переносу електронів по електрон-транспортному ланцюгу (ЕТЛ) (табл. 2).

Табл. 1. Вміст хлорофілів (мг/г сирої маси) у листках бука звичайного (Fagus silvatica L.) та тополі пірамідальної (Topulus pyramidalis Moenoh.) Покутсько-Буковинських Карпат, що характеризуються різним рівнем антропогенного навантаження $(\mathrm{M} \pm \mathrm{m}, \mathrm{n}=4)$

\begin{tabular}{|c|c|c|c|c|c|}
\hline \multirow[b]{2}{*}{ Об'єкт } & \multirow[b]{2}{*}{ Показник } & \multicolumn{4}{|c|}{ Варіант досліду } \\
\hline & & $\begin{array}{c}\text { контроль }(100 \%), \\
\text { заповідна зона НПП }\end{array}$ & $\begin{array}{c}\text { зона стаціонарної } \\
\text { рекреації }\end{array}$ & $\begin{array}{c}\text { господарська зона } \\
\text { НПП }\end{array}$ & $\begin{array}{c}\text { прилеглі до } \\
\text { НПП території }\end{array}$ \\
\hline \multirow{3}{*}{ Fagus silvatica $\mathrm{L}$. } & хл "a" & $4,84^{ \pm 0,12}(100 \%)$ & $4,72^{ \pm 0,11}(97,5 \%)$ & $4,30^{ \pm 0,15}(88,8 \%)$ & $4,05^{ \pm 0,15}(82,8 \%)$ \\
\hline & хл "b" & $1,52^{ \pm 0,08}(100 \%)$ & $1,35^{ \pm 0,09}(88,8 \%)$ & $1,20^{ \pm 0,08}(78,9 \%)$ & $1,02^{ \pm 0,04}(67,7 \%)$ \\
\hline & $\frac{\text { хл "a" }}{\text { хл "b" }}$ & 3,18 & 3,50 & 3,58 & 3,97 \\
\hline \multirow{3}{*}{$\begin{array}{c}\text { Topulus pyramidalis } \\
\text { Moenoh. }\end{array}$} & хл "a" & $6,20^{ \pm 0,25}(100 \%)$ & $6,05^{ \pm 0,15}(97,6 \%)$ & $5,80^{ \pm 0,12}(93,5 \%)$ & $5,60^{ \pm 0,25}(90,3 \%)$ \\
\hline & хл "b" & $2,1^{ \pm 0,10}(100 \%)$ & $2,00^{ \pm 0,09}(95,2 \%)$ & $1,80^{ \pm 0,10}(85,7 \%)$ & $1,65^{ \pm 0,07}(78,6 \%)$ \\
\hline & $\frac{\text { хл "a" }}{\text { хл "b" }}$ & 2,95 & 3,02 & 3,22 & 3,39 \\
\hline
\end{tabular}

Примітка: різниця достовірна при $\mathrm{p}<0,05 ; \mathrm{M}$ - середньоарифметичний показник; $\mathrm{m}$ - помилка середньоарифметичного показника; р - ймовірність помилки досліду.

Табл. 2. Активність реакції Хілла (мкм К글 $(\mathrm{CN})_{6} /$ мг хлорофілу за год) у деяких представників дендрофлори Покутсько-Буковинських Карапт $(\mathrm{M} \pm \mathrm{m}, \mathrm{n}=4)$

\begin{tabular}{|c|c|c|c|c|}
\hline \multirow{2}{*}{ Об'єкт } & \multicolumn{4}{|c|}{ Варіант досліду } \\
\cline { 2 - 5 } & заповідна зона НПП & $\begin{array}{c}\text { зона стаціонарної } \\
\text { рекреації НПП }\end{array}$ & $\begin{array}{c}\text { господарська зона } \\
\text { НПП }\end{array}$ & $\begin{array}{c}\text { прилеглі до НПП ландшафти } \\
\text { традиційної господарської } \\
\text { діяльності }\end{array}$ \\
\hline Fagus silvatica L. & $81,3^{ \pm 3,50}(100 \%)$ & $75,5^{ \pm 2,40}(92,9 \%)$ & $74,2^{ \pm 3,50}(91,3 \%)$ & $63,5^{ \pm 2,70}(78,1 \%)$ \\
\hline $\begin{array}{c}\text { Topulus pyramidalis } \\
\text { Moenoh. }\end{array}$ & $94,60^{ \pm 4,50}(100 \%)$ & $93,6^{ \pm 4,20}(98,9 \%)$ & $85,5^{ \pm 5,10}(90,4 \%)$ & $82,2^{ \pm 4,05}(86,9 \%)$ \\
\hline
\end{tabular}

Примітка: різниця достовірна при $\mathrm{p}<0,05$ 
Табл. 3. Коефіцієнт кореляції $(r)$ показників фотосинтетичного апарату та рівня забруднення атмосферного повітря в екотопах Покутсько-Буковинських Карпат

\begin{tabular}{|c|c|c|c|}
\hline \multirow[b]{2}{*}{ Екотоп } & \multirow[b]{2}{*}{ Фотосинтетичний показник } & \multicolumn{2}{|c|}{ Показник стану атмосферного повітря } \\
\hline & & $\begin{array}{c}\text { кількість легких негативних } \\
\text { аероіонів }\end{array}$ & загальне мікробне число \\
\hline \multirow{3}{*}{ Заповідна зона НПП } & вміст хлорофілу "а" & 0,81 & 0,69 \\
\hline & вміст хлорофілу "b" & 0,89 & 0,76 \\
\hline & активність реакції Хілла & 0,95 & 0,77 \\
\hline \multirow{3}{*}{$\begin{array}{c}\text { Зона стаціонарної рекреації } \\
\text { НПП }\end{array}$} & вміст хлорофілу "а" & 0,68 & 0,51 \\
\hline & вміст хлорофілу "b" & 0,73 & 0,55 \\
\hline & активність реакції Хілла & 0,75 & 0,58 \\
\hline \multirow{3}{*}{ Господарська зона НПП } & вміст хлорофілу "а" & $-0,25$ & 0,30 \\
\hline & вміст хлорофілу "b" & $-0,31$ & 0,36 \\
\hline & активність реакції Хілла & $-0,34$ & 0,39 \\
\hline \multirow{3}{*}{$\begin{array}{c}\text { Території традиційних госпо- } \\
\text { дарських ландшафтів, прилег- } \\
\text { лих до НПП }\end{array}$} & вміст хлорофілу "а" & $-0,83$ & 0,09 \\
\hline & вміст хлорофілу "b" & $-0,87$ & 0,10 \\
\hline & активність реакції Хілла & $-0,90$ & 0,12 \\
\hline
\end{tabular}

Переважне руйнування хлорофілу "б" під впливом забруднення атмосферного повітря може бути однією 3 причин деградації пігментного комплексу хлоропластів і вагомим регулювальним фактором процесів світлової фази фотосинтезу. Першочергово ці зміни проявляються в порушенні переносу електронів по ЕТЛ, про що свідчать отримані нами дані стосовно швидкості реакції Хілла. Отриманий результат вказує на можливі зміни в структурі фотосинтетичного апарату за умови зростання забруднення атмосферного повітря.

Проведений нами порівняльний аналіз фотосинтетичних показників та раніше отриманих нами (Masikevych, 2018; Masikevych, Heretsun et. al., 2018) результатів стосовно рівня атмосферного забруднення за аероіонними та мікробіологічними показниками досліджених екотопів, дав змогу сформувати відповідну кореляційну матрицю взаємозалежності зазначених показників (табл. 3).

На порівно чистих, за показниками атмосферного повітря, територіях (заповідній зоні та зоні стаціонарної рекреації НПП) існує тісна позитивна кореляція між вмістом легких негативних аероіонів, з одного боку, та нагромадженням зелених пігментів і активністю фотофізичних процесів, з іншого. У міру забруднення атмосферного повітря, в зоні активного ведення господарської діяльності, тісна позитивна кореляція між зазначеними показниками змінюється на негативну. Внаслідок забруднення атмосферного повітря викидами автомобільного транспорту, індивідуального опалення, лісопереробних підприємств, на цих територіях спостерігається гальмування фотосинтетичних процесів у деревовидних форм рослин. Треба зазначити, що ці території поступаються також відсотком лісового покриття, що можна пояснити, окрім проведення суцільних рубань у регіоні, також впливом якості атмосферного повітря на процес лісопоновлення, особливо при витіснені корінних порід похідними.

Між рівнем бактеріального забруднення атмосферного повітря та активністю фотосинтетичних показників (див. табл. 3) загалом спостерігається зазначена вище тенденція, проте тіснота кореляційних зв'язків дещо слабша і наближається до нульової позначки.

Висновки. Внаслідок проведених досліджень вивчено вміст хлорофілів та їх співвідношення в листках бука звичайного (Fagus silvatica L.) та тополі пірамідальної (Topulus pyramidalis L.), що вегетують у заповідній зоні, зоні стаціонарної рекреації, господарській зоні на- ціонального природного парку "Вижницький" та прилеглих територіях традиційного ведення господарства. Досліджено інтенсивність процесів світлової фази фотосинтезу шляхом вивчення активності реакції Хілла в рослин зазначених вище територій різного природоохоронного статусу. На підставі отриманих результатів порівняльного аналізу фотосинтетичних показників та даних стосовно рівня атмосферного забруднення, за аероіонними та мікробіологічними показниками досліджених екотопів, побудовано кореляційну матрицю взаємозалежності зазначених показників. Показано доцільність використання фотосинтетичних показників дендрофлори заповідної зони об'єктів природоохоронних територій як індикаторів стану екологічної безпеки атмосферного повітря.

\section{References}

Demkiv, T. M., Konopelnyk, O. I., \& Shopa, Ya. I. (2008). Fundamentals of the theory of errors of physical quantities. Lviv: Vydavnychyj centr LNU im. I. Franka, $40 \mathrm{p}$. Retrieved from: https://physics.lnu.edu.ua/wp-content/uploads/pohybky.pdf

Gavrylenko, V. F., \& Khandobyna, M. E. (1975). A large practicum on plant physiology. Moscow: Higher school, 392 p. [In Russian].

Lucyshyn, O. G., Radchenko, V. G., Palapa, N. V., \& Yavorovskyj, P. P. (2010). Macromorphological changes of the response-response of plant organisms of tree street plantations of the Kyiv metropolis at stress level of technogenic pollution. Dop. NAN Ukrayiny, 6, 180-187. Retrieved from: https://dspace.nbuv.gov.ua/handle/ $\underline{123456789 / 29850}$

Masikevych, A. Yu., Heretsun, H. M., Masikevych, Yu. G., Kolotylo, M. P., \& Yaremchuk, V. M. (2018). Atmospheric protection as a composition of environmental safety of the region. East European Science Journal, 12(40), 30-34. Retrieved from: https://eesajournal.com/wp-content/uploads/EESA_journal_1_part_11.pdf

Masikevych, A. Yu., Kolotylo, M. P., \& Yaremchuk, V. M. (2018). Estimation of atmospheric air within the functional zones of the Vizhnitsky National Nature Park. (Ser. Novi rishennya v suchasnykh texnologiyakh). Visnyk NTU "KhPI", 26(1302), 2, 78-82. https://doi.org/10.20998/2413-4295. 2018.26.36

Masikevych, Yu. G. (2011). Changes in the indices of the photosynthetic apparatus of urban dendroflora under atmospheric air pollution. (Ser. Biologiya). Naukovi zapysky Ternopilskogo nacionalnogo pedagogichnogo universytetu im. V. Gnatyuka, 4(49), 66-69. Retrieved from: https://catalog.library.tnpu.edu.ual naukovi_zapusku/biolog/2011/biol_11_4.pdf

Masikevych, Yu. G., \& Masikevych, A. Yu. (2011). The study of the possibility of using photosynthetic indicators to determine the status of the urban ecosystem. Scientific Bulletin of UNFU, 21(16), 316319. Retrieved from: https://old.nltu.edu.ua/nv/archive/2011/21_16 1316_mas.pdf 
Mudrak, O. V. (Ed.), Mudrak, G. V., Polishhuk, V. M., et al. (2014). Standards of nature of Vinnitsa region. Vinnycya: TOV "NilanLTD", $532 \mathrm{p}$.

Odukalecz, I. O. (2011). Morphologist's physiological changes of woody plants under atmospheric pollution. Pytannya bioindykaciyi to ekologiyi, 16(1), 54-78. Retrieved from: https://sites.znu.edu.ua/ bioindication/issues/2011-16-1/_dukal.pdf

Popek, R., Przybysz, A., Gawrosska, H., Klamkowski, K., \& Gawrosski, S. W. (2018). Impact of particulate matter accumulation on the photosynthetic apparatus of roadside woody plants growing in the urban conditions. Ecotoxicology and Environmental Safety, 163, 56-62. https://doi.org/10.1016/j.ecoenv.2018.07.051

Shepelyuk, M. O., Kovalevskyj, S. B., \& Kytayev, O. I. (2017). Chlorophyll fluorescence and its induction changes in leaves of woody plants in the urban environment of Lutsk. Scientific Bulletin of UNFU, 27(1), 101-105. https://doi.org/10.15421/40270122
Shupranova, L. V., Lykholat, Yu. V., Khromykh, N. O., Gryczaj, Z. V., et al. (2017). Response of the photosynthetic apparatus of the extrasonic vegetation of the Quercus robur steppe vegetation to atmospheric pollution by transport emissions. Biosyst. Divers., 25(4), 268-273. Retrieved from: https://doi.org/10.15421/011741

Ting Lu, Xintao Lin, Jian Chen, Dongming Huang, \& Ming Li. (2019). Atmospheric particle retention capacity and photosynthetic responses of three common greening plant species under different pollution levels in Hangzhou. (Vol. 20). Global Ecology and Conservation. October. https://doi.org/10.1016/j.gecco.2019.e00783

Yusypiva, T., \& Vegerych, V. (2014). Dynamics of photosynthetic pigment content in leaves of woody plants under man-made growth conditions. (Ser. Biology). Bulletin of the University of Lviv, 65, 189-196. Retrieved from: https://prima.lnu.edu.ua/faculty/biologh/ wis/65/5/19/19.pdf

A. Yu. Masikevich

Bukovynian State Medical University, Chernivtsi, Ukraine

\section{PHOTOSYNTHETIC INDICATORS OF THE ATMOSPHERIC AIR POLLUTION STATUS OF THE POKUTSKO-BUKOVINIAN CARPATHIANS}

The study has shown that the photosynthetic indices of the dendroflora of the protected areas are not yet sufficiently used as benchmarks to identify the level of atmospheric air pollution of traditional landscapes. The correlation between photosynthesis processes and the level of atmospheric pollution in ecotopes differing in the level of anthropogenic loading is investigated. The protected area of Vizhnitsky National Nature Park was chosen as the standard. Methods of spectrophotometry, centrifugation, and correlation analysis were used for the research. The content of chlorophylls a and b, their correlation and Hill reaction activity in leaves of beech (Fagus silvatica L.) and pyramidal poplar (Topulus pyramidalis L.) vegetating in the Pokutsko-Bukovynian Carpathian region were studied. The intensity of photosynthesis light phase processes in the conditions of different levels of atmospheric air pollution are found to correlate closely with the accumulation of green pigments in plants, in particular chlorophyll b. As a consequence, the decrease in the relative content of chlorophyll b leads to the inhibition of the electron transport (Hill reaction) and the processes of light phase photosynthesis. The correlation matrix of the interdependence of the photosynthetic parameters studied and the level of atmospheric pollution by air ions and microbiological parameters are compiled. The expediency of using photosynthetic indicators of the dendroflora of protected areas as indicators of the environmental safety of the atmospheric air of the region is shown. In the future, it is of interest to find out the dynamics of the phytocenosis productivity changes in the Pokutsko-Bukovynian Carpathians and their phytopathological resistance, in connection with the increase in the level of atmospheric pollution and global climate change.

Keywords: ecotope; protected reference territories; dendroflora; photosynthetic indicators; state of the air environment; correlation matrix. 